\title{
Correction to: Moral and Vocational Dilemmas Meet the Common Currency Hypothesis: a Contribution to Value Commensurability
}

\section{Eleonora Viganò ${ }^{1} \cdot$ Edoardo Lombardi Vallauri $^{2}$}

Published online: 28 October 2019

(C) Springer Nature B.V. 2019

\section{Correction to: Review of Philosophy and Psychology https://doi.org/10.1007/s13164-019-00448-7}

In the initial online publication, the second author's given name should have been displayed in full and in the running head the names were not properly abbreviated. The correct authors names are stated above and the original article has been corrected.

Publisher's Note Springer Nature remains neutral with regard to jurisdictional claims in published maps and institutional affiliations.

The online version of the original article can be found at https://doi.org/10.1007/s13164-019-00448-7

Eleonora Viganò

eleonora.vigano@ibme.uzh.ch

Edoardo Lombardi Vallauri

edoardo.lombardivallauri@uniroma3.it

1 Institute of Biomedical Ethics and History of Medicine, University of Zurich, Winterthurerstrasse 308006 Zürich Switzerland

2 Dipartimento di Lingue, Letterature e Culture Straniere, Università degli Studi Roma Tre, Via Ostiense, 23600146 Roma Italy 